\title{
Radiocarbon chronology of the mammoth site at Niederweningen, Switzerland: Results from dating bones, teeth, wood, and peat
}

\author{
Irka Hajdas $^{\mathrm{a}, *}$, Georges Bonani ${ }^{\mathrm{b}}$, Heinz Furrer ${ }^{\mathrm{c}}$, Andreas Mäder ${ }^{\mathrm{d}}$, Werner Schoch ${ }^{\mathrm{e}}$ \\ ${ }^{a}$ PSI c/o ETH Zürich, AMS C14 lab, Schafmattstrasse. 20, 8093 Zürich, Switzerland \\ bInstitut für Teilchenphysik, ETH Zürich, AMS C14 lab, Schafmattstrasse 20, 8093 Zürich, Switzerland \\ ${ }^{\mathrm{c}}$ Paläontologisches Institut und Museum der Universität Zürich, Karl Schmid-Strasse 4, 8006 Zürich, Switzerland \\ ${ }^{\mathrm{d}}$ Kantonsarchäologie Zürich, Stettbachstrasse 7, 8600 Dübendorf, Switzerland \\ ${ }^{\mathrm{e}}$ Labor für Quartäre Hölzer, Unterrütistrasse 17, 8135 Langnau a.A., Switzerland
}

Available online 11 December 2006

\begin{abstract}
The peat section at Niederweningen is a site of spectacular excavations of numerous bones of mammoth and other animals that was first recognized in the late 19th century. In 1987/1990, new excavations provided more peat material, which was radiocarbon dated to $33,000{ }^{14} \mathrm{C}$ years BP and $42,000{ }^{14} \mathrm{C}$ years BP. The first AMS radiocarbon ages of mammoth bones from $1890 / 1891$ excavations placed the age between $33,000{ }^{14} \mathrm{C}$ years BP and $35,000{ }^{14} \mathrm{C}$ years BP. In this study, new results were obtained on bones, teeth, wood and peat from the layer that buried the mammoths. The ages confirm that the mammoths as well as the peat section, in which they were found, are older than $40,000{ }^{14} \mathrm{C}$ years BP. In order to explain the discrepancy between the previous chronology and the new results, two preparation techniques were applied for the dating of bones. An organic fraction called "collagen" used to obtain the first radiocarbon ages was dated as well as gelatine prepared using the modified Longin method. The differences of up to 7000 years between ages obtained on collagen and gelatine fractions show contamination of the collagen fraction with modern carbon. The oldest age of $45,870 \pm 1080{ }^{14} \mathrm{C}$ years BP was obtained on base cleaned gelatine from mammoth bone. This age is close to an age of $45,430 \pm 1020{ }^{14} \mathrm{C}$ years BP obtained for the peat layer that buried the mammoths.
\end{abstract}

(C) 2006 Elsevier Ltd and INQUA. All rights reserved.

\section{Introduction}

\subsection{Mammoths and radiocarbon dating}

The history of the Late Pleistocene woolly mammoth (Mammuthus primigenius) and its disappearance is of great interest to anthropology and climate change studies. The main subject of these studies is the spatial and temporal distribution of mammoth bones. Radiocarbon dating provides a direct dating tool of mammoth remains. For example, dating of numerous mammoth sites showed that during the last glacial maximum (LGM) woolly mammoth crossed the land bridge of Beringia to join the American mammoth (Mammuthus columbi) and then extinct very rapidly at the Pleistocene/Holocene boundary in the area. Based on radiocarbon dating of mammoth sites, it has also

\footnotetext{
*Corresponding author.

E-mail address: hajdas@phys.ethz.ch (I. Hajdas).
}

been shown that an isolated population survived in the Alaskan Beringia until the early Holocene with the youngest bones dated at $7000{ }^{14} \mathrm{C}$ years BP that were found on St. Paul Island (Dale Guthrie, 2004). In Europe, a southward expansion has been documented by numerous bones and artefacts left by Homo sapiens, who co-existed with mammoths for thousands of years. The wealth of bones found in Europe, Siberia and North America provides an enormous potential for the reconstruction of the final 40,000 years of woolly mammoths' history and the environment in which they lived. Based on radiocarbon dating the most southward presence of mammoth reaching the Crimea and the Caucasus lasted until 20,000 years ago (Arslanov et al., 1998). From that time mammoth began to gradually retreat to the northern regions of Arctic Siberia. Recent radiocarbon chronologies of bones from Wrangel Island document Holocene refugia of mammoth, where in isolated environments the species survived until about $3700{ }^{14} \mathrm{C}$ years BP (Kuzmin et al., 2003; Kuzmin and Orlova, 2004). 
Radiocarbon ages of bones found in Switzerland show the presence of the woolly mammoth until the late Glacial $\left(13,705 \pm 55{ }^{14} \mathrm{C}\right.$ years BP for the skeleton of Praz Rodet,

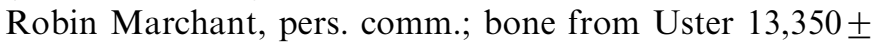
$260{ }^{14} \mathrm{C}$ years BP). Older bones dated between 18,000 and $22,000{ }^{14} \mathrm{C}$ years BP have been found in gravel pits in the area of Rafz, Hüntwangen, Wil and Weiach (Rhine valley). An older find from Obfelden (Reuss valley) was dated to 37,000-43,000 ${ }^{14} \mathrm{C}$ years BP (Hünermann, 1985). Recently the tusk found at Sylleux Ajoie, Swiss Jura was dated at $31,595 \pm 1335{ }^{14} \mathrm{C}$ years BP (Aubry et al., 2005). A peat (lignite) horizon from the area of Gondiswil, which was dated by pollen analyses to an age of 55,000-48,000 years (Wegmüller, 1992), contained isolated mammoth teeth.

The mammoths found in the peat bog of Niederwenigen were dated in late 1980 ties by radiocarbon at $33,000-35,000{ }^{14} \mathrm{C}$ years $\mathrm{BP}$ (Schlüchter, 1994). These radiometric dates for the peat section as well as for the mammoth bones have shown that the find is more recent than assumed on the basis of the first pollen analyses. The pollen studies implied that the peat was deposited in the Last Interglacial and at the beginning of the last glaciation, so the age of the peat was estimated to be around 100,000 years (Welten, 1988). Palaeoclimatic correlation with Gossau, another Swiss site that has recorded the warm phases of the Oxygen Isotope Stage 3 (OIS3), carries great potential for improved radiocarbon chronology of terrestrial records of this period (Geyh and Schlüchter, 1998; Preusser et al., 2003). Moreover, the most recent 2003/2004 excavations at Niederweningen provide material for detailed multidisciplinary palaeoclimate studies of the peat sections that contained mammoths' fossils.

Problems with radiocarbon ages older than $40,000{ }^{14} \mathrm{C}$ years are often considered to result from contamination by modern carbon since this age corresponds to about seven ${ }^{14} \mathrm{C}$ half-lives and only $\sim 0.8 \%$ of the initial amount is left, and an addition of small amounts of modern carbon can significantly change radiocarbon ages. The main methodological aspect addressed in this study is the reliability of radiocarbon ages of mammoth bones from the Niederweningen site. Wood, plant macrofossils and peat provide excellent material for radiocarbon dating, which are used to cross-check radiocarbon ages of bones.

\subsection{Radiocarbon dating of bones}

Bones, teeth and ivory belong to material that is frequently dated by the radiocarbon method. Over the last 55 years, numerous bones of animals, humans and last Neanderthals have been dated. Moreover artifacts made of ivory and turtle shell provide organic material suitable for dating. Archeologists have always valued this possibility although the literature reports frequent discordant ages obtained on charcoal and bone from the same stratigraphic levels. Apparently, ages obtained on bones tend to be younger than those obtained on charcoal, which implies contamination with younger carbon. One possible source of younger carbon would be carbonate crystallized on the surface of the bones though this should be removed during the first acid step of bone treatment. The other source of contamination is post depositional incorporation of humic substances into the bone material either due to humification processes occurring in the bone and/or due to an interaction with the burial environment (van Klinken and Hedges, 1995). Younger humic acids migrating with groundwater might attach to the porous bone structure and build cross-links within the collagen. Therefore, the main focus of the treatment methods for radiocarbon dating is removing such contamination. Over the past decades attempts have been made to separate different organic fractions of the bone, which might yield most accurate radiocarbon ages.

Although bone mineral is partly made of carbonateapatite that contains carbon suitable for dating, separation of the organic fraction is the prevailing method for dating bone material and ivory. Dried, defatted fresh bones contain about $20 \%$ of collagen. The degree of decomposition and the amount of protein-remnants are important factors in isotopic studies of bone material. These can be estimated by $\mathrm{C} / \mathrm{N}$ ratio and/or amino acid composition. The organic fraction is often described as 'collagen' or protein-remnants, i.e. the rest remaining after the dissolution of the mineral part. The preparative techniques focus on avoiding the intrusive humus fraction. In the method proposed by Longin (1971) only the acid soluble, gelatine fraction is separated from 'collagen'. An additional cleaning of 'collagen' with base before extracting the gelatine fraction is used to dissolve and remove humic substances (Arslanov and Svezhentsev, 1993; Piotrowska and Goslar, 2002). Other methods involve removal of the light humic fraction $(<30 \mathrm{kDa})$ using ultra filtration (Brown et al., 1988; Higham et al., 2006) or cleaning protein-remnants in ion-exchange columns (Law and Hedges, 1989). van Klinken et al. (1994) showed that a separation of collagen specific peptides obtained from collagenase cleavage yields organic material that can be separated using chromatography (HPLC) and then AMS radiocarbon dated. Nelson (1991) used a reaction of the dye nihydrin and $\alpha$-amino acids to obtain carbon dioxide from gelatine.

\subsection{Radiocarbon dating of wood and peat}

Chemical pre-treatment of wood and peat focuses on removing contamination with either old or modern carbon. The first treatment with an acid solution removes carbonate contaminates. After washing with distilled water the following bath in a weak base dissolves humic acids. The final wash is a repeated hot acid bath applied to remove modern carbon incorporated into the sample structure during the base step when modern atmospheric $\mathrm{CO}_{2}$ dissolves in alkali solution. The last step is shorter than the other two and is finalized by rinsing at normal $\mathrm{pH}$. The ABA (or AAA for acid-alkali-acid) method is 
commonly used in laboratories. However, several studies (Hattè et al., 2001 and references given therein) have shown that in some materials the alkali step of ABA might be responsible for contamination with modern carbon from atmospheric $\mathrm{CO}_{2}$ dissolved in the base and incorporated into the sample structure. Such contamination cannot be entirely removed by the last acid step if the commonly used $\mathrm{HCl}$ solution is applied. The effect of contamination becomes significant when old material is ${ }^{14} \mathrm{C}$ dated. Hattè et al. (2001) proposed alternative treatments, which can be applied to samples that are susceptible to contamination of their inner structure. For example modern carbonates, which replace functional groups in old wood, can be detached from the structure by stronger agents such as sulfuric acid.

Another modification of the ABA method involves oxidizing as the last step of pre-treatment. Bird et al. (1999) applied two methods of oxidizing, using a highly oxidizing agent of acid dichromate solution, the so-called 'wet oxidation' (ABOX), and pre-combustion of the sample at lower temperatures $\left(330\right.$ and $\left.630^{\circ} \mathrm{C}\right)$ prior to the final combustion at $850^{\circ} \mathrm{C}$. They used these two complementary methods and showed that the oldest ages of a very old charcoal, i.e., the most effective removal of contamination, is achieved when 'wet oxidized' samples are also pre-combusted prior to total combustion.

\section{Radiocarbon chronology of the Niederweningen Mammoth site}

\subsection{Site and problematic radiocarbon ages}

The mammoth remains at Niederweningen site, near Zürich, have been discovered in 1890 during railway constructions work. The bones that appeared in the gravel pit caught public attention and interest of the natural scientist A. Lang. Thank to his involvement the finds of the so-called 'Mammutloch' (mammoth pit) were excavated and published (Lang, 1892). Bones that originate from at least five mammoths and a mammoth calf accompanied by fossils of other fauna (cf. Furrer et al., 2007) were found in a peat section underneath a gravel and silt layer. More detailed geological studies followed in 1983 and 1987 when sediment cores were drilled at two locations near the original mammoth find (Schlüchter, 1988). Similarly to the description made by Lang (1892), these cores showed that the contact of the peat layer with the overlaying lake sediments showed numerous deformations. The newest excavations 2003/2004 confirm this picture of a very complicated stratigraphy with the surface of the peat being deformed (Furrer et al., 2007). Three peat layers have been documented at the Niederweningen site. The uppermost peat horizon, which was documented in the 2003 excavations (Furrer et al., 2007), contained numerous fragments of wood and macrofossils. The first radiocarbon ages obtained on wood samples from this layer (upper peat) resulted in ages older than $40,000{ }^{14} \mathrm{C}$ years, thus close to the radiocarbon age of the middle peat (Table 1). The middle peat at Niederweningen, which buried the mammoths, is usually about $1 \mathrm{~m}$ thick but often reduced by sedimentary deformation and erosion to thin lenses. Locally thin lens-like peat horizons were found below and above the main middle peat. This peat section contained mammoth bones and is therefore correlated to the $1890 / 1891$ 'mammoth pit'. However, the radiocarbon age of a bison bone from the 'mammoth pit' 1890/1891 and a not specified bone found in a construction pit 1987 yielded ages between 33,000 and $34,000{ }^{14} \mathrm{C}$ years BP (Schlüchter, 1994), i.e., significantly younger than the ages obtained in 2003 on both wood from the upper peat and bones from the middle peat, respectively. At that point the problematic chronology required closer examination of possible sources of contamination of bones. Moreover, a new blank material allowed resolving of minimum ages of wood and bones (Table 1).

\subsection{Background correction and sample preparation}

For samples as old as the mammoths from Niederweningen, background correction obtained by the measurement of blank $\left({ }^{14} \mathrm{C}\right.$ free $)$ material and the preparation technique of bones are the crucial factors. All radiocarbon ages are calculated following the procedure outlined by Stuiver and Polach (1977). Typically, blank samples are prepared from ${ }^{14} \mathrm{C}$ free material, such as anthracite, coal, graphite or marble, to track down the amount of ${ }^{14} \mathrm{C}$ added during the preparative process (contamination). The measured ${ }^{14} \mathrm{C} /{ }^{12} \mathrm{C}$ ratio of a blank sample is subtracted from the ${ }^{14} \mathrm{C} /{ }^{12} \mathrm{C}$ values of all samples used for dating, unless their ${ }^{14} \mathrm{C} /{ }^{12} \mathrm{C}$ is close to the value measured for the blank sample. In such cases, radiocarbon ages close to the limit of the radiocarbon dating method are reported as minimum ages (older than). In 2004, additional analyses were performed with a new blank material (Ceylon graphite) showing a lower degree of contamination with ${ }^{14} \mathrm{C}$. The new blank values were significantly lower than the ${ }^{14} \mathrm{C} /{ }^{12} \mathrm{C}$ values measured for the Niederweningen samples and allowed calculation of radiocarbon ages for the newly prepared bones and wood samples.

An improved preparation technique was applied for the separation of carbon from bone material compared to the dating of the 'collagen' fraction. Bone material (ca. $2 \mathrm{~g}$ ) was crushed and pulverized. Because this preparation requires at least $1 \mathrm{~g}$ of powder, some of the samples were too small and were only treated with $0.5 \mathrm{M} \mathrm{HCl}$ to remove the mineral part of the bone and to separate the 'collagen' fraction (COL) (Fig. 1). The pulverized samples were treated with acid, base and in the last step gelatine was obtained by dissolution in slightly acidic water at $80^{\circ} \mathrm{C}$ (Fig. 1). From the dried material, the GB fraction (gelatine treated with base) and the insoluble fraction of rest material of GB preparation (RGB) were then placed in precooked quartz tubes together with $\mathrm{CuO}$, evacuated, torch sealed and combusted at $950^{\circ} \mathrm{C}$. Graphitization and 
Table 1

Results of AMS radiocarbon dating of bones, peat and wood from the Niederweningen Mammoth Site

\begin{tabular}{|c|c|c|c|c|c|c|c|}
\hline $\begin{array}{l}\text { Laboratory } \\
\text { number }\end{array}$ & $\begin{array}{l}\text { Peat } \\
\text { section }\end{array}$ & Sample number & Material & Fraction & $\begin{array}{l}{ }^{14} \mathrm{C} \text { age } \pm 1 \sigma \\
(\mathrm{BP})\end{array}$ & $\delta^{13} \mathrm{C}(\%)$ & $\begin{array}{l}\text { Measurement } \\
\text { year }\end{array}$ \\
\hline ETH-28095 & Upper & FK 123 & Wood & & $\begin{array}{r}>40330 \pm 470 \\
42620 \pm 780\end{array}$ & $\begin{array}{l}-25.2 \pm 1.2 \\
-24.4 \pm 1.2\end{array}$ & $\begin{array}{l}2003 \\
2004\end{array}$ \\
\hline ETH-30229 & Upper & Zapfen nr.117 & $\begin{array}{l}\text { Macrofossils } \\
\text { Picea }\end{array}$ & & $44520 \pm 1140$ & $-29.0 \pm 1.2$ & 2005 \\
\hline ETH-28092 & Middle & $\mathrm{A} / \mathrm{V} 4430$ & Mammoth bone & $\begin{array}{l}\text { COL } \\
\text { COL } \\
\text { GB } \\
\text { RGB }\end{array}$ & $\begin{array}{l}40910 \pm 830 \\
37910 \pm 520 \\
45870 \pm 1080 \\
38340 \pm 570\end{array}$ & $\begin{array}{l}-24.4 \pm 1.2 \\
-19.8 \pm 1.2 \\
-19.3 \pm 1.2 \\
-19.8 \pm 1.2\end{array}$ & $\begin{array}{l}2003 \\
2004 \\
2005 \\
2005\end{array}$ \\
\hline ETH-28093 & Middle & $\mathrm{A} / \mathrm{V} 4431$ & Mammoth tooth & $\mathrm{COL}$ & $\begin{array}{r}>38630 \pm 410 \\
36550 \pm 450\end{array}$ & $\begin{array}{l}-22.4 \pm 1.2 \\
-21.0 \pm 1.2\end{array}$ & $\begin{array}{l}2003 \\
2004\end{array}$ \\
\hline ETH-28094 & Middle & FK 121 & Wood & & $>40480 \pm 470$ & $-24.0 \pm 1.2$ & 2003 \\
\hline ETH-29171 & Middle & $454,06-454,05$ & Peat & & $\begin{array}{r}>41580 \pm 510 \\
45430 \pm 1020\end{array}$ & $\begin{array}{l}-25.4 \pm 1.2 \\
-22.2 \pm 1.2\end{array}$ & $\begin{array}{l}2004 \\
2005\end{array}$ \\
\hline ETH-29172 & Middle & $454,00-454,01$ & Peat & & $>41140 \pm 490$ & $-22.8 \pm 1.2$ & 2004 \\
\hline ETH-30070 & Middle & A/II 191 & $\begin{array}{l}\text { Frog, bones } \\
\text { fragments }\end{array}$ & $\mathrm{COL}$ & $37840 \pm 520$ & $-21.3 \pm 1.2$ & 2005 \\
\hline ETH-30071 & Middle & $\mathrm{A} / \mathrm{V} 4580$ & $\begin{array}{l}\text { Mammoth rib } \\
\text { bone }\end{array}$ & $\mathrm{COL}$ & $41730 \pm 730$ & $-21.1 \pm 1.2$ & 2005 \\
\hline ETH-30072 & Middle & A/V 1373 & $\begin{array}{l}\text { Horse, tooth } \\
\text { fragments }\end{array}$ & $\mathrm{COL}$ & $30600 \pm 290$ & $-21.8 \pm 1.2$ & 2005 \\
\hline ETH-30073 & Middle & A/V 1382 & $\begin{array}{l}\text { Horse, skull } \\
\text { bone }\end{array}$ & $\mathrm{COL}$ & $25890 \pm 200$ & $-21.3 \pm 1.2$ & 2005 \\
\hline ETH-30073 & Middle & $\mathrm{A} / \mathrm{V} 1382$ & & GB & $31790 \pm 310$ & $-20.5 \pm 1.2$ & 2005 \\
\hline ETH-30073 & Middle & $\mathrm{A} / \mathrm{V} 1382$ & & RGB & $29570 \pm 290$ & $-21.3 \pm 1.2$ & 2005 \\
\hline
\end{tabular}

Conventional (Libby) radiocarbon ages (with 1 sigma error) were calculated following Stuiver and Polach (1977). Bone organic fractions dated were ‘collagen' COL, gelatine cleaned with base GB, insoluble fraction RGB. Measurements in years 2004 and 2005 were performed with a new blank material.

measurements are described by Bonani et al. (1987) and Hajdas et al. (2004), respectively.

The modified preparation techniques of Hattè et al., (2001) and the ABOX technique of Bird et al., (1999), respectively, were applied to clean peat and wood samples. This involved a replacement of the last step (weak $\mathrm{HCl}$ ) of the ABA protocol treatment with weak $\mathrm{HCl}$ with a $\mathrm{H}_{2} \mathrm{SO}_{4}$ treatment. The wood and the fragments of a Picea cone (macrofossils) were treated with $0.1 \mathrm{M} \mathrm{K}_{2} \mathrm{Cr}_{2} \mathrm{O}_{7}$ in a $2 \mathrm{M}$ solution of $\mathrm{H}_{2} \mathrm{SO}_{4}$.

\section{Results}

The effect of using a new blank material is apparent for the ages determined for wood samples from the upper peat layer (Table 1). The measured ${ }^{14} \mathrm{C} /{ }^{12} \mathrm{C}$ ratio of a sample prepared from the new ${ }^{14} \mathrm{C}$-free material (Ceylon Graphite) was significantly lower (factor 2) than the value obtained from previously used anthracite. This allowed calculation of ages for wood and bone samples. All but two peat samples, which were prepared in 2004 and 2005, resulted in finite numbers. A radiocarbon age of $45,430 \pm 1020{ }^{14} \mathrm{C}$ years BP was obtained for one of the samples from the middle peat layer, which was re-measured with the new blank material.

The mammoth bone sample A/V 4430 (ETH-28092) and the tooth sample A/V4431 (ETH-28093) obtained on the 'collagen' fraction resulted in ages of $40,910 \pm 830{ }^{14} \mathrm{C}$ years $\mathrm{BP}$ and $>38,630{ }^{14} \mathrm{C}$ years BP (Table 1). Although these two ages are coherent, the measurement on the rest of the 'collagen' fraction resulted in younger ages of $37,910 \pm 520{ }^{14} \mathrm{C}$ years BP (bone) and $36,550 \pm 450{ }^{14} \mathrm{C}$ years BP (tooth). These results indicate that the 'collagen' fraction used for these analyses was contaminated. The new analyses, which involved the Longin method of separation gelatine with an additional base cleaning step (GB), were only possible for the bone sample (A/V 4430) because the amount of material needed for preparation was not sufficient for the tooth sample (A/V 4431). The age of $45,870 \pm 1080{ }^{14} \mathrm{C}$ years $\mathrm{BP}$ obtained for the gelatine fraction GB is the oldest obtained so far for this bone (A/V 4430). The radiocarbon age of the insoluble fraction $\mathrm{RGB}$, which remained after gelatine separation, is $38,340 \pm 570{ }^{14} \mathrm{C}$ years BP i.e., younger than the gelatine fraction and closer to the ages of 'collagen' fraction. Up to date only an age of $41,730 \pm 730{ }^{14} \mathrm{C}$ years BP was 
measured on a 'collagen' fraction of a rib bone of mammoth found in 2004.

Bones of other animals were found in the middle peat section together with mammoth bones. Small fragments of

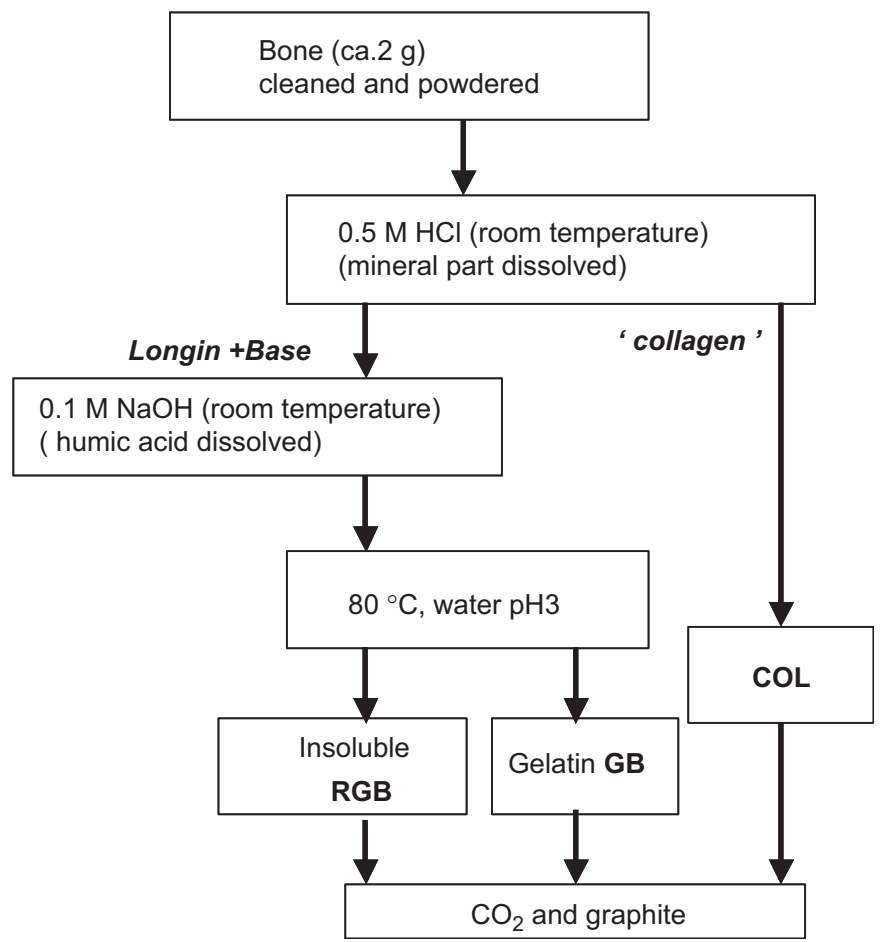

Fig. 1. Sample preparation used for bones. The 'collagen' fraction (COL) was used in earlier studies (2003 and 2004) and for bones, which could not be prepared using the modified Longin method due to the small amount of material or difficulty in sample preparation. This sample preparation yields two fractions: gelatine cleaned with base (GB) and the insoluble rest fraction (RGB). When available, the RGB fraction is measured as a control sample. frog bones (A/II 191) excavated in 2004 were too small for gelatine separation and therefore the 'collagen' fraction was dated, which gave an age of $37,840 \pm 520{ }^{14} \mathrm{C}$ years BP. This age is younger than the mammoth though contamination of the 'collagen' fraction cannot be ruled out.

The bones of other animals, which were found in 1890/ 1891, show even younger ages. The ages measured on samples of a horse tooth (A/V 1373) and a horse skull (A/V 1382) are close to $30,000{ }^{14} \mathrm{C}$ years BP. As in the case of the mammoth bone, the gelatine fraction GB of the horse skull provided the oldest age of $31,790 \pm 310{ }^{14} \mathrm{C}$ years $\mathrm{BP}$, with the RGB fraction younger by $\sim 2000$ years. The younger ages of the bones recovered during the 1890 excavations could be explained by contamination by varnish, if it was used for the conservation of the bones, although no traces of such treatment were observed prior to sample preparation.

\section{Discussion}

\subsection{Age of the middle peat}

The age of $44,520 \pm 1140{ }^{14} \mathrm{C}$ years BP for the top of this section (Fig. 2) is based on the results of dating the peat sample taken at an elevation of $454.6-454.05 \mathrm{~m}$ a.s.1. (profile 9/2003). This radiocarbon age was obtained in a second run with the lower blank values. The sample of peat taken from the same profile but $5 \mathrm{~cm}$ below the top sample resulted in ages older than $41,140{ }^{14} \mathrm{C}$ years $\mathrm{BP}$ (measurement with the old blank). The oldest age obtained on the bones of mammoth is $45,430 \pm 1020{ }^{14} \mathrm{C}$ years $\mathrm{BP}$ and the age of the wood sample FK121 dated in 2003 is $>40,480$ ${ }^{14} \mathrm{C}$ years $\mathrm{BP}$.

The correlation of the $1890 / 1891$ 'mammoth pit' excavations and the middle peat is based on geologic

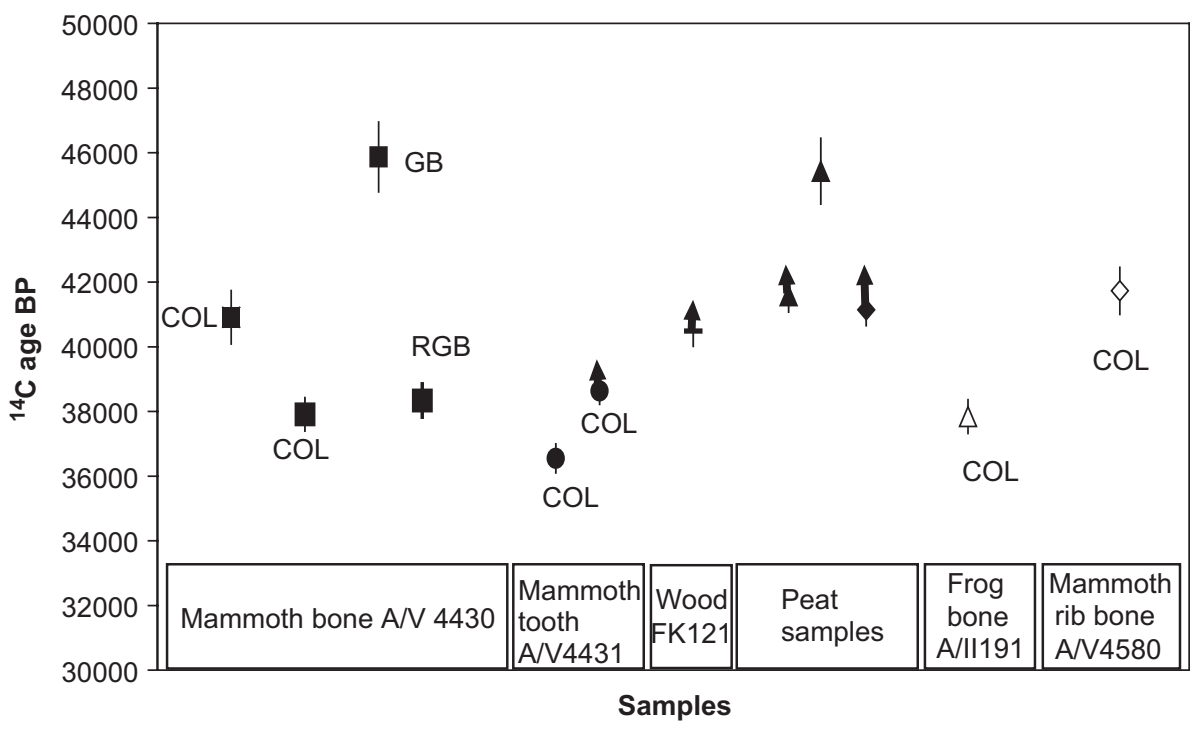

Fig. $2 .{ }^{14} \mathrm{C}$ chronology of the middle peat section based on ${ }^{14} \mathrm{C}$ analyses performed for samples from this layer: mammoth bone $\mathrm{A} / \mathrm{V} 4430$ (squares), mammoth tooth A/V4431 (filled circles), wood sample FK121 (bar), peat sample from the top of middle section 454,06-05 m a.s.1. (filled triangles), peat sample 454,00-01 m a.s.l. (filled diamond), bones of frog A/II 191 (triangle), rib bone A/V 4580 (diamond). The arrows indicate minimum ages (Table 1). 
(geometric) interpretations and the presence of mammoth bones. The peculiar young ages of the horse tooth and skull, which were found in the 1890/1891 'mammoth pit', pose a problem for such a correlation. Additional radiocarbon dating of various specimens from the old excavation of the 'mammoth pit' and the construction pit of 2004, which is at the nearly identical location, might be helpful in solving this problem.

\subsection{Age of the upper peat}

The two ${ }^{14} \mathrm{C}$ measurements on samples prepared from wood fragment FK123 resulted in ages older than $40,000{ }^{14} \mathrm{C}$ years BP (Fig. 3). The age $\left(>40,330{ }^{14} \mathrm{C}\right.$ years BP) obtained in 2003 was a minimum age because of the higher blank values. The age of $42,620 \pm 780{ }^{14} \mathrm{C}$ years, which was measured in 2004 on the same sample of wood, is close to the age of the middle peat. Additional dating performed on macrofossils (Picea cone) resulted in an age of $44,520 \pm 1140{ }^{14} \mathrm{C}$ years BP. This thin upper peat horizon was visible only in the 2003 excavation, in the core taken in 1985 and the construction pit 1987 south of the 1890/1891 'mammoth pit' (Schlüchter, 1988). Pollen analyses place this layer in a different pollen zone than the middle peat layer (Drescher-Schneider et al., 2007); therefore a younger age has been expected. There are two plausible explanations of such an old age for the upper peat section that corroborate pollen data. The first involves reworking of old organic material, which is visible as a layer rich in organic debris. In this case, the age of the matrix (peat and pollen) could be younger than the wood deposited in it. Such possibility can only be confirmed or ruled out when reliable radiocarbon ages on the peat/pollen fraction are available, which is planned for future analyses. The second explanation for a 'too old' radiocarbon age of this layer involves the complicated nature of the ${ }^{14} \mathrm{C}$ time scale and/or brevity of the cold phase between the warm period of the middle peat deposit and the upper peat deposit. A tentative

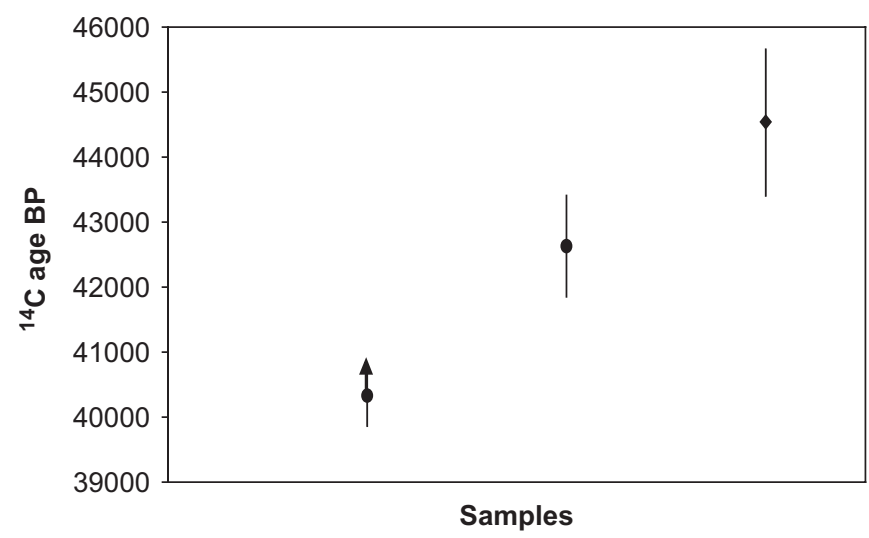

Fig. 3. Radiocarbon ages of wood (filled circles) and Picea cone (diamond) from the upper peat section. The arrow indicates minimum age obtained for sample of wood FK123, which was dated in 2003.

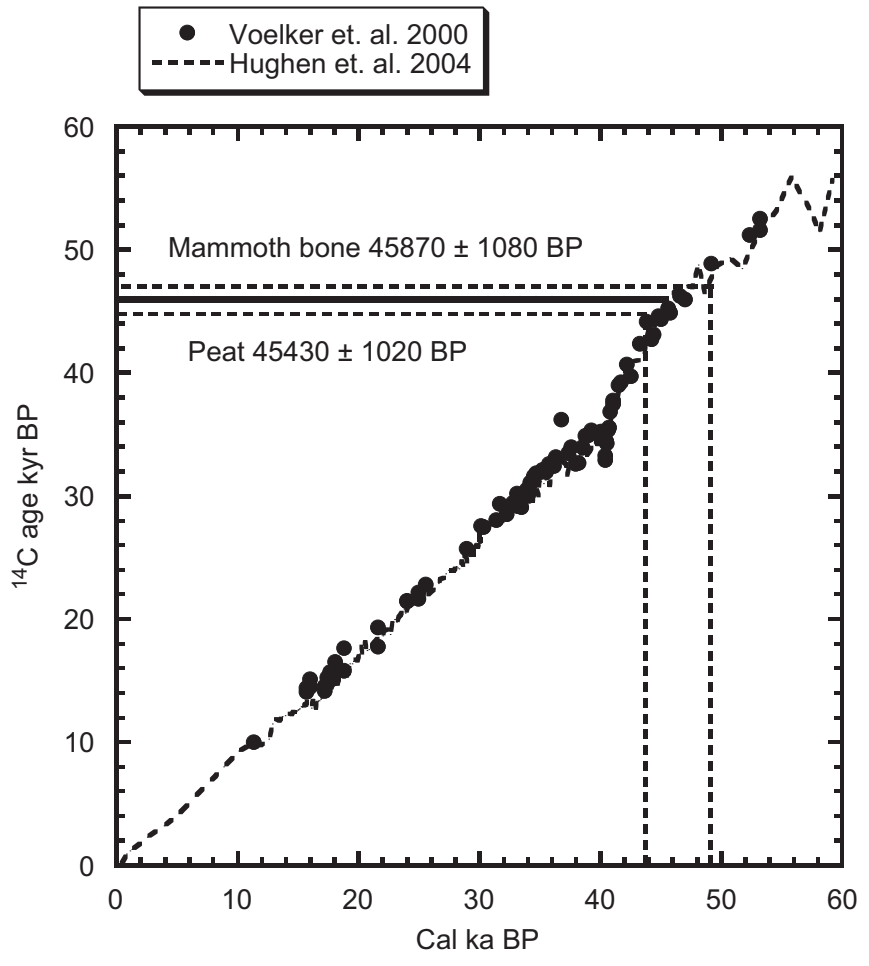

Fig. 4. Preliminary estimation of calendar age for the middle peat and the mammoth bone. The data set from the Iceland Sea (Voelker et al., 2000) and from Cariaco Basin (Hughen et al., 2004) provide the preliminary calibration data sets.

correlation to radiocarbon dated marine records (Fig. 4) shows that the time interval on the calendar time scale for these two ${ }^{14} \mathrm{C}$ dates might be as long as 5000 years.

\subsection{Timing of OIS3 climatic events in Switzerland}

Apart from the spectacular find of mammoths' bones, the Niederweningen peat section provides an insight into the environment in which the mammoths lived. The peat section with very well-preserved organic material allowed for reconstructions of the vegetation and climate changes based on pollen, plant macrofossils, and beetle fauna (Coope, 2007; Drescher-Schneider et al., 2007; ). Correlation to the Gossau site (Schlüchter et al., 1987) is based on our radiocarbon chronology and Infrared Stimulated Luminescence ages (IRSL) (Preusser and Degering, 2007), and supported by beetle fauna (Jost-Stauffer et al., 2001, 2005; Coope, 2007) as well as pollen analyses (DrescherSchneider et al., 2007). The timing of the two lignites at Gossau is based on radiocarbon and U/Th ages (Geyh and Schlüchter, 1998) and luminescence ages (Preusser, 1999; Preusser et al., 2003). The upper lignite is significantly younger (ca. 29,000 years) than the peat sections at Niederweningen. However the lower lignite, which has three distinct seams separated by silty intercalations, at least partially correlates to the Niederweningen middle peat section (Schlüchter et al., 1987). The radiocarbon age of the upper seam is ca. $33,000-40,000{ }^{14} \mathrm{C}$ years BP whereas the 
lower seam was deposited between 45,000 and $54,000{ }^{14} \mathrm{C}$ years BP. The radiocarbon age of $45,420 \pm 1200{ }^{14} \mathrm{C}$ years BP for the top of the lower seam from Gossau (Schlüchter et al., 1987) is very close to the age obtained for the top of the middle peat horizon at our site. The bracketing IRSL ages obtained for the Niederweningen middle peat layer date the deposit between $\sim 40,000$ and $\sim 75,000$ years as compared to the timing obtained by luminescence dating of the Gossau lower lignite, which places the deposit of the lower seam between 50,000 and 100,000 years ago (Preusser, 1999; Preusser et al., 2003). Thus, these two terrestrial sites appear to contain deposits, which provide a unique opportunity to study and date the climatic events that took place in Switzerland during the OIS3.

\section{Conclusions}

An improved sample preparation of bone samples allowed radiocarbon dating of the Niederweningen Mammoth Site. The radiocarbon ages obtained for bones, wood and peat samples from the Niederweningen Site indicate that the mammoth(s), which were found at in the peat, died in the last phase of the middle peat formation around 45,000 years ago. The ages of wood and the Picea cone from the overlying thin layer of the upper peat are only slightly younger than the middle peat section.

\section{Acknowledgements}

This work was performed at the AMS Facilities, jointly operated by the Swiss Federal Institute of Technology, Zurich and Paul Scherrer Institut, Villigen, Switzerland.

\section{References}

Arslanov, K.A., Svezhentsev, Y.S., 1993. An improved method for radiocarbon dating fossil bones. Radiocarbon 35, 387-391.

Arslanov, K.A., Cook, G.T., Gulliksen, S., Harkness, D.D., Kankainen, T., Scott, E.M., Vartanyan, S., Zaitseva, G.I., 1998. Consensus dating of mammoth remains from Wrangel Island. Radiocarbon 40, 289-294.

Aubry, D., Braillard, L., Guelat, M., Stalder, L., Stahl Gretsch, L., 2005. Mensch und Umwelt. Archäologie der Schweiz 28, 6-16.

Bird, M.I., Ayliffe, L.K., Fifield, L.K., Turney, C.S.M., Cresswell, R.G., Barrows, T.T., David, B., 1999. Radiocarbon dating of "old" charcoal using a wet oxidation, stepped-combustion procedure. Radiocarbon 41, 127-140.

Bonani, G., Beer, J., Hofmann, H., Synal, H.A., Suter, M., Wölfli, W., Pfleiderer, C., Junghans, C., Münnich, K.O., 1987. Fractionation, precision and accuracy in ${ }^{14} \mathrm{C}$ and ${ }^{13} \mathrm{C}$ measurements. Nuclear Instruments and Methods in Physics Research B 29, 87-90.

Brown, T.A., Nelson, D.E., Vogel, J.S., Southon, J.R., 1988. Improved collagen extraction by modified Longin method. Radiocarbon 30, 171-177.

Coope, R., 2007. Coleoptera from the 2003 excavations of the mammoth skeleton at Niederweningen, Switzerland. Quaternary International (this volume).

Dale Guthrie, R., 2004. Radiocarbon evidence of mid-Holocene mammoths stranded on an Alaskan Bering Sea island. Nature 429, 746-749.
Drescher-Schneider, R., Jacquat, Ch., Schoch, W., 2007. Palaeobotanical investigations at the mammoth site of Niederweningen, Switzerland. Quaternary Internatinal (this volume).

Furrer, H., Graf, H.R., Mäder, A., 2007. The mammoth site of Niederweningen, Switzerland. Quaternary International (this volume).

Geyh, M.A., Schlüchter, C., 1998. Calibration of the C time scale beyond 22,000 BP. Radiocarbon 40, 475-482.

Hajdas, I., Bonani, G., Thut, J., Leone, G., Pfenninger, R., Maden, C., 2004. A report on sample preparation at the ETH/PSI AMS facility in Zurich. Nuclear Instruments and Methods in Physics Research Section B 223-224, 267-271.

Higham, T.F.G., Jacobi, R.M., Ramsey, C.B., 2006. AMS radiocarbon dating of ancient bone using ultrafiltration. Radiocarbon 48, 179-195.

Hattè, C., Morvan, J., Noury, C., Paterne, M., 2001. Is classical acid-alkali-acid treatment responsible for contamination? An alternative proposition. Radiocarbon 43, 177-182.

Hughen, K., Lehman, S., Southon, J., Overpeck, J., Marchal, O., Herring, C., Turnbull, J., 2004. ${ }^{14} \mathrm{C}$ activity and global carbon cycle changes over the past 50,000 years. Science 303, 202-207.

Hünermann, K.A., 1985. Eiszeit-Säugetiere aus dem Kanton Zürich. Vierteljahrsschrift der Naturforschenden Gesellschaft Zürich 130, 229-250.

Jost-Stauffer, M., Coope, G.R., Schlüchter, C., 2001. A coleopteran fauna from the middle Wurm (Weichselian) of Switzerland and its bearing on palaeobiogeography, palaeoeclimate and palaeoecology. Journal of Quaternary Science 16, 257-268.

Jost-Stauffer, M., Coope, G.R., Schlüchter, C., 2005. Environmental and climatic reconstructions during marine Oxygen Isotope Stage 3 from Gossau, Swiss Midlands, based on coleopteran assemblages. Boreas 34, 53-60.

Kuzmin, Y.V., Orlova, L.A., 2004. Radiocarbon chronology and environment of woolly mammoth (Mammuthus primigenius Blum) in northern Asia: results and perspectives. Earth-Science Reviews 68, 133-169.

Kuzmin, Y.V., Orlova, L.A., Zolnikov, I.D., 2003. Dynamics of the mammoth (Mammuthus primigenius) population in Northern Asia: radiocarbon evidence. Deinsea. Annual of the Natural History Museum 9, 221-237.

Lang, A., 1892. Geschichte der Mammutfunde. Ein Stück Geschichte der Paläontologie, nebst einem Bericht über den schweizerischen Mammutfund in Niederweningen 1890/91. Neujahrsblatt hrsg. von Naturf. Ges. auf das Jahr 1892 XCIV, 2-35.

Law, I.A., Hedges, R.E.M., 1989. A semiautomated bone pretreatment system and the pretreatment of older and contaminated samples. Radiocarbon 31, 247-253.

Longin, R., 1971. New method of collagen extraction for radiocarbon dating. Nature 230, 241-242.

Nelson, D.E., 1991. A new method for carbon isotopic analysis of protein. Science 251, 552-554.

Piotrowska, N., Goslar, T., 2002. Preparation of bone samples in the Gliwice radiocarbon laboratory for AMS radiocarbon dating. Isotopes in Environmental and Health Studies 38, 267-275.

Preusser, F., 1999. Luminescence dating of fluvial sediments and overbank deposits from Gossau, Switzerland: fine grain dating. Quaternary Science Reviews 18, 217-222.

Preusser, F., Degering, D., 2007. Luminescence dating of the Niederweningen mammoth site, Switzerland. Quaternary International (this volume).

Preusser, F., Geyh, M.A., Schlüchter, C., 2003. Timing of late Pleistocene climate change in lowland Switzerland. Quaternary Science Reviews 22, 1435-1445.

Schlüchter, C., 1988. Neue geologische Beobachtungen bei der Mammutfunstelle in Niederweningen (Kt. Zürich). Vierteljahrsschrift der Naturforschenden Gesellschaft Zürich 133, 99-108.

Schlüchter, C., 1994. Das Wehntal-Eine Schlüsselregion der Eiszeitforschung, 28.Jahrheft des Unterländer Museumvereins 1994/95, Oberweningen, pp. 4-24.

Schlüchter, C., Maisch, M., Suter, J., Fitze, P., Keller, W.A., Burga, C.A., Wynistorf, E., 1987. Das Schieferkohlenprofil von Gossau (Kanton Zürich) 
und seine stratigraphische Stellung innerhalb der letzten Eiszeit. Vierteljahrsschrift der Naturforschenden Gesellschaft Zürich 132, 135-174.

Stuiver, M., Polach, H.A., 1977. Reporting of ${ }^{14} \mathrm{C}$ data. Radiocarbon 19 , 355-363.

van Klinken, G.J., Bowles, A.D., Hedges, R.E.M., 1994. Radiocarbon dating of peptides isolated from contaminated fossil bone-collagen by collagenase digestion and reversed-phase chromatography. Geochimica et Cosmochimica Acta 58, 2543-2551.

van Klinken, G.J., Hedges, R.E.M., 1995. Experiments on collagen-humic interactions: speed of humic uptake, and effects of diverse chemical treatments. Journal of Archaeological Science 22, 263-270.
Voelker, A.H.L., Grootes, P.M., Nadeau, M.-J., Sarnthein, M., 2000. Radiocarbon levels in the Iceland sea from $25-53 \mathrm{kyr}$ and their link to the earth's magnetic field intensity. Radiocarbon 42, 437-452.

Wegmüller, S., 1992. Vegetationsgeschichtliche und stratigraphische Untersuchungen an Schieferkohlen des nördlichen Alpenvorlandes. Denkschrift der schweizerischen Akademie der Naturwissenschaften 192, 1-82.

Welten, M., 1988. Neue pollenanalystische Ergebnisse über das Jüngere Quartär des nördlichen Alpenvorlandes der Schweiz (Mittel- und Jungpleistozän). Beiträge zur Geologischen Karte der Schweiz N.F. vol. $162.40 \mathrm{pp}$. 